\title{
Possibility and Effects of Recycling Vinyl-Banner Waste into Fired-Clay Bricks for Home Industry in Lampung
}

\author{
R Ikhwanuddin ${ }^{1}$, O F T Maryana ${ }^{2}$, M Y Darmawan ${ }^{2}$, V L Ipmawan ${ }^{2}$, S \\ Anggini $^{2}$, A Lailani ${ }^{2}$ \\ ${ }^{1}$ Engineering Physics Department, Institut Teknologi Sumatera, Lampung, Indonesia \\ ${ }^{2}$ Physics Department, Institut Teknologi Sumatera, Lampung, Indonesia
}

\begin{abstract}
Bricks are regarded as important material in building constructions. Basically, brick is processed by mixing clay and water then burnt under high temperature for a certain duration. Previous study in Indonesia shows that mixing local clay with additional materials could improve its characteristic, especially in terms of water absorption potentiality. Lampung has home industries which run brick making business traditionally. Moreover, this year Indonesian government has been organizing regional elections which attract campaigners to produce more vinyl banners as advertising media. As the event has already passed, vinyl banners eventually become environmental issue since they are not yet well managed. The aim of this study is to investigate the possibility and effect of red bricks mixtures along with vinyl banner waste. Firedclay bricks dimensions including length, width, and height are $19 \mathrm{~cm}, 9.5 \mathrm{~cm}$, and $5 \mathrm{~cm}$ respectively. Measurement has done by employing water absorption tests. Waste-added bricks absorb more water than the conventional one, about $11 \%$ higher. However, rice-husk-ash-added bricks perform similar to the normal bricks, it has slow rate of water absorption. Absorption rate of waste-added bricks also fast and exceed the conventional and RHA-added bricks. Modified red bricks surfaces are uneven, they show cracks and rough edges.
\end{abstract}

\section{Introduction}

Environment-friendly building materials nowadays are receiving high attention and this business is undoubtedly progressing in Indonesia. The momentousness in arising use of environment-friendly building materials are as follows: environmental regulations, impact on the environment and human health, decarbonisation objectives and utilisation of materials at the end of the life-cycle [1]. Bricks made from fired clay has been known as one of the oldest and most ecological building materials as it is created of natural raw materials. Several studies have shown that mechanical properties of red bricks can be mixed with other waste materials to obtain new quality [1][2].

Human activities produce various amounts of unwanted substance in parallel with its main purpose of activity. Particularly in political interest, most people are not environmentally aware that printed media for political campaigns are polluting ecosystem. Printed media made of vinyl banner is favourably used in Indonesia. Even though online media is accessible, this cannot fully replace printed media in order to promote each political group ideas. Consequently, vinyl banners are massively found unused straight after election period. Other than vinyl banner materials, several studies [2][3][4] have been conducted to investigate the possibilities of recycling waste materials into a new product as sustainable building material. 
Rice husk ash (RHA) addition in the manufacturing process of fired clay bricks has been studied at least by Munasih [4] and De Silva [3]. Rice husk ash (RHA) addition shows potential since it is happened improving mechanical properties while lowering water absorption [4]. Recent studies [5], brick dough is developed with other waste materials to promote the life-cycle of waste product. This study will also incorporate waste into building material. In the context of recycling, the present study focuses on using printed media waste (vinyl) in clay brick compounds for civil construction. However, the physical test taking place in this study is limited to only on visual appearance, product dimension, and water absorption test. Although the ceramic industry is highly promising for the final disposal of solid wastes, little is known about the reuse of printed media waste in clay ceramics.

The main objective of this study is to investigate the possibility and the effects of printed media waste (vinyl) additives on physical appearance and porosity of fired-clay bricks.

\section{Clay Bricks}

Clay is a soft, loose, earthy material containing particles with a grain size of less than 4 micrometres $(\mu \mathrm{m})$. It forms as a result of the weathering and erosion of rocks containing the mineral group feldspar over vast spans of time [6]. Consisting of clayey soil and water, a brick dough can be moulded to become clay brick. It is shaped, naturally dehydrated, and heated in in the workshop. Known as the oldest and most used building material, clay brick also has been manufactured at the waterfronts where suitable soil could easily be found [7] [8]. Soil is inexpensively affordable, environmentally friendly, and plentiful obtainable in nature [9]. Clay soil also easily can be found in farming area. It has unique characteristics such as plastically soft and weak on wet environment, hardened on dry state, and condensedly solid after burnt.

\section{Recommended Design}

Standardization in industry is usually required to ensure consistency and quality of certain products. The necessary aspects which must have in fired clay brick such as visual appearance, dimension, and compressive strength are commonly demanded. According to SK SNI (Standar Nasional Indonesia) S $04-1989$ - F issued by National Standard Institution on brick standard, it is recommended to follow the national guideline, see Table 1 and Table 2 as follow.

Table 1. Brick dimension based on Indonesian National Standard [10].

\begin{tabular}{lccc}
\multirow{2}{*}{ Module } & \multicolumn{3}{c}{ Dimension $(\mathrm{cm})$} \\
\cline { 2 - 4 } & Breadth & Width & Length \\
\hline M-5a & 6.5 & 9 & 19 \\
M - 5b & 6.5 & 14 & 19 \\
M -6 & 5.5 & 11 & 23 \\
\hline
\end{tabular}

Size deviations that are regulated according to SNI (Standar Nasional Indonesia) are shown in Table 2.

Table 2. Allowed brick dimension deviation [10].

\begin{tabular}{|c|c|c|c|c|c|c|}
\hline \multirow{3}{*}{ Class } & \multicolumn{6}{|c|}{ Maximum Deviation $(\mathrm{cm})$} \\
\hline & \multicolumn{3}{|c|}{$M-5 a \& M-5 b$} & \multicolumn{3}{|c|}{$M-6$} \\
\hline & Breadth & Width & Length & Breadth & Width & Length \\
\hline 25 & 0.2 & 0.3 & 0.5 & 0.2 & 0.3 & 0.5 \\
\hline 50 & 0.2 & 0.3 & 0.5 & 0.2 & 0.3 & 0.5 \\
\hline 100 & 0.2 & 0.3 & 0.4 & 0.2 & 0.3 & 0.4 \\
\hline
\end{tabular}




\begin{tabular}{lllllll}
150 & 0.2 & 0.2 & 0.4 & 0.2 & 0.2 & 0.4 \\
200 & 0.2 & 0.2 & 0.4 & 0.2 & 0.2 & 0.4 \\
250 & 0.2 & 0.2 & 0.4 & 0.2 & 0.2 & 0.4 \\
\hline
\end{tabular}

Additionally, compressive strength test usually has been done in the study of clay brick properties. National standard also addresses this, this effort has been done to promote class differentiation on brick toughness and its durability in market. Among other brick quality that is regarded important is the ability to absorb water. An author [10] argues that ability to absorb water must be controlled in order to avoid water loss from mortar. Wall construction which does not achieve uniformity in absorbing water will result an irregular appearance due to cracks on wall surface. Hence, this study limits to only investigate brick appearance, its dimension, and water absorption ability.

Even though BSN (Badan Standar Nasional) or National Standard Institution in Indonesia has established fired clay brick a standard as mentioned above, this experiment design employs local practice. Each brick workshop has custom and tradition inherited generation by generation. Brick dimension differs from the standard, mould box of clay dough and the manual process can be seen in Figure 1. Also, the dimension inside of a wood block to shape wet clay is available in Figure 2. This clay brick is closed to $\mathrm{M}-5$ a module in Table 1, only with smaller breadth.
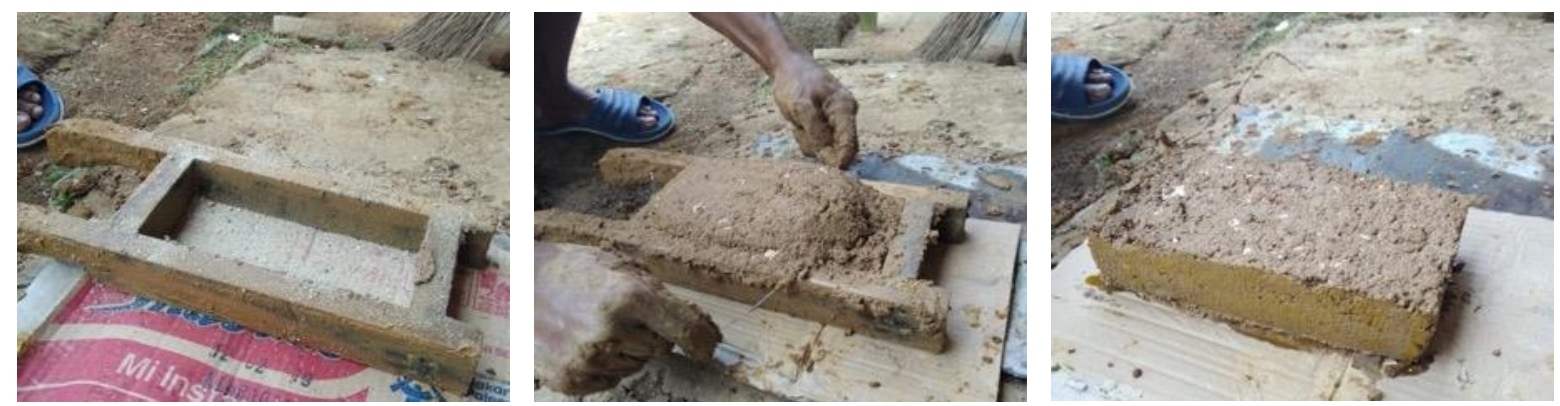

Figure 1. Manual moulding with a wood block and a wire.
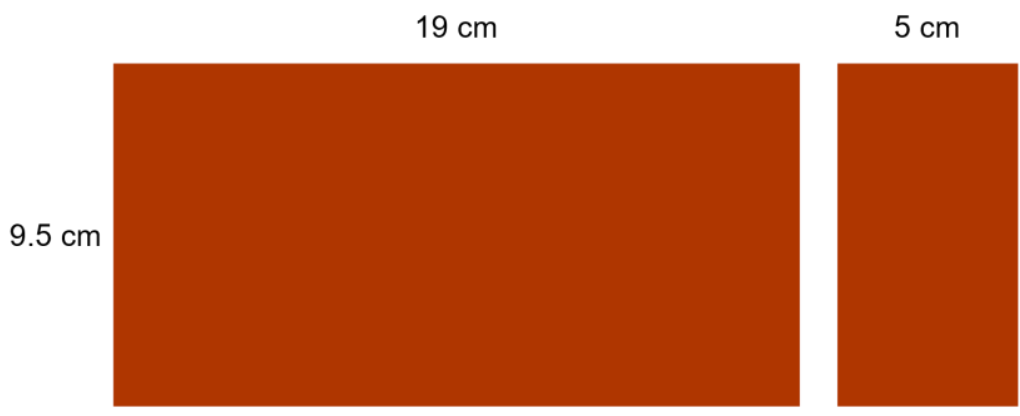

Figure 2. Clay brick dimension.

Manual moulding results sometimes are not quite satisfying, this technique is slow and highly probable manufacturing inconsistent products. Supposing that circumstances, brickmakers often rent automatic machine to help them moulding the bricks.

\section{Materials and Methods}

The experiments were done with local clay, vinyl banner, water, rice husk ash (RHA), place of mould, plastic bag, and scissors. The vinyl wastes are divided into two groups of treatment, first it is carved into very small pieces and second it is sliced into long-small threads using scissors. The wastes are consisting 
of two type vinyl banners, they are $440 \mathrm{gr} / \mathrm{meter}^{2}$ and $280 \mathrm{gr} / \mathrm{meter}^{2}$, the differences are thickness and density. Then clay soil is prepared with some amount of water. The specific composition of samples gathered are dictated in Table 3. Each composition is fully mixed, then labelled and bagged with a huge plastic. All six bags are left out for three to four days in order to achieve wet uniformity.

Table 3. Composition of sample experiments.

\begin{tabular}{ccccclc}
\hline No & $\begin{array}{c}\text { Clay } \\
\text { Soil } \\
(\mathrm{kg})\end{array}$ & $\begin{array}{c}\text { Water } \\
\text { Volume } \\
(\text { liter })\end{array}$ & $\begin{array}{c}\text { Vinyl } \\
\text { Banner } \\
(\text { gram })\end{array}$ & $\begin{array}{c}\text { Rice } \\
\text { Husk } \\
\text { Ash } \\
(\mathrm{gram})\end{array}$ & Vinyl Banner Waste & $\begin{array}{c}\text { Experiment } \\
\text { Label }\end{array}$ \\
\hline 1 & 5 & 2 & 80 & 0 & $440 \mathrm{~g} / \mathrm{m}^{2}$ small pieces & $\mathrm{C} 4$ \\
2 & 5 & 2 & 80 & 0 & $440 \mathrm{~g} / \mathrm{m}^{2}$ long-small threads & $\mathrm{P} 4$ \\
3 & 5 & 2 & 50 & 0 & $280 \mathrm{~g} / \mathrm{m}^{2}$ small pieces & $\mathrm{C} 2$ \\
4 & 5 & 2 & 50 & 0 & $280 \mathrm{~g} / \mathrm{m}^{2}$ long-small threads & $\mathrm{P} 2$ \\
5 & 5 & 2.2 & 80 & 80 & $440 \mathrm{~g} / \mathrm{m}^{2}$ small pieces & $\mathrm{SC} 4$ \\
6 & 5 & 2.2 & 0 & 320 & - & $\mathrm{S}$ \\
7 & 5 & 2.2 & 0 & 0 & - & $\mathrm{M}$ \\
\hline
\end{tabular}

In this experiment the amount of fired-clay bricks made are not plenty. Hence, wet clay brick is shaped manually using a place of mould and a wire. Wet clays and its additives are placed inside a wood block and sliced with a wire to form a perfect brick block, see Figure 1. Separately, normal bricks on number 7 in Table 3 are made using automatic machine so that it can be shaped faster and it is also more suitable for mass production.
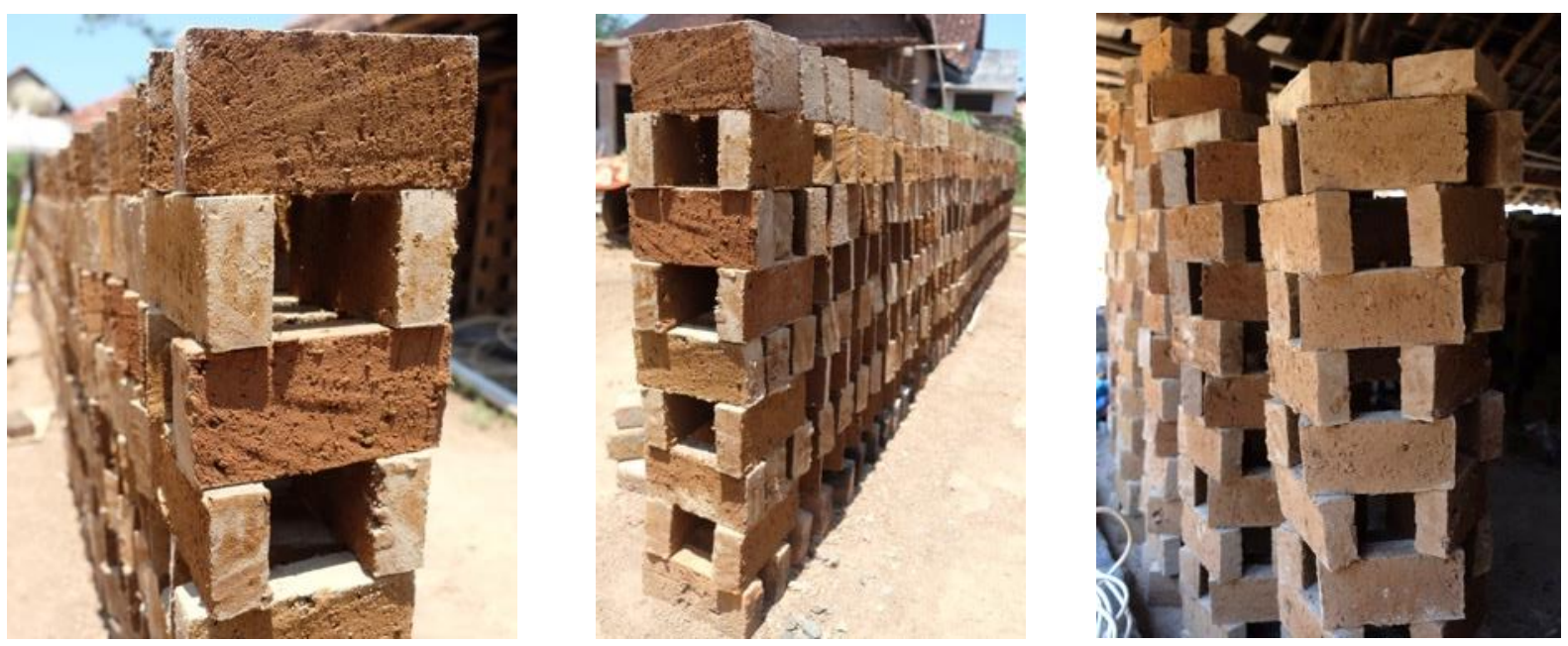

Figure 3. A pile of sun-dried clay bricks.

All shaped clay bricks are sun-dried for about a week (see Figure 3) and then burnt in a kiln using rice husk for three to five days. This technique employs slow burning to ensure heat uniformity in the pile, see Figure 4. Sun-dried clay bricks are stacked and some section will deliberately unfilled. The gaps between them are supplied with a lot of rice husk. Everyday a worker will check the kiln and put on more rice husk if gap shows up. 

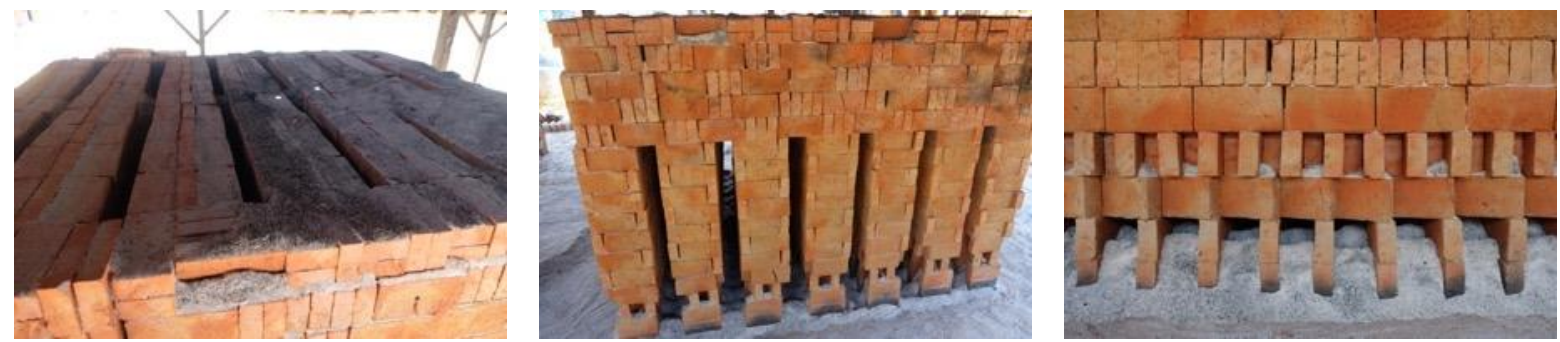

Figure 4. End phase of firing process with rice husk in a workshop.

All fired-clay bricks available are tested in terms of water absorption capacity. This test is carried out in accordance with ASTM 67-07 [11]. The bricks are immersed in the water for 1 minute, 5 minutes, and further 24 hours. Furthermore, the saturated wet weight $\left(W_{s}\right)$ is measured. The amount of water absorbed $\left(W_{a}\right)$ by the brick is subsequently calculated as in Equation (1) where $W_{d}$ is dry weight of the brick.

$$
W_{a}=\frac{W_{s}-W_{d}}{W_{d}} \times 100 \%
$$

\section{Results and Discussion}

Seven types of clay bricks we made were successfully burnt uncracked. Each type has been made several units, enough to achieve minimum quantity for test purpose. Even though clay bricks well solidify and have some red brick colour as they usually do, they do not have same visual or shape appearance. Several pictures taken (from Figure 5 through Figure 10) point out that vinyl-added clay bricks do not have bold looks and also have distorted quality as from a perfect brick block. See Figure 11, this is normal firedclay brick which is used as control in this study, these bricks also show good appearance and nearly flat on all sides.

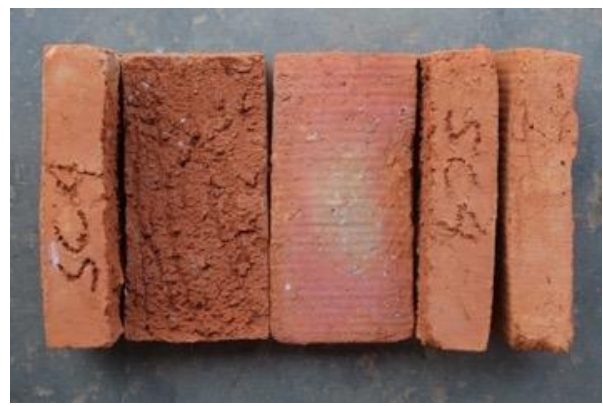

Figure 5. SC4: RHA + Vinyl 440gr $/ \mathrm{m}^{2}$ pieces.

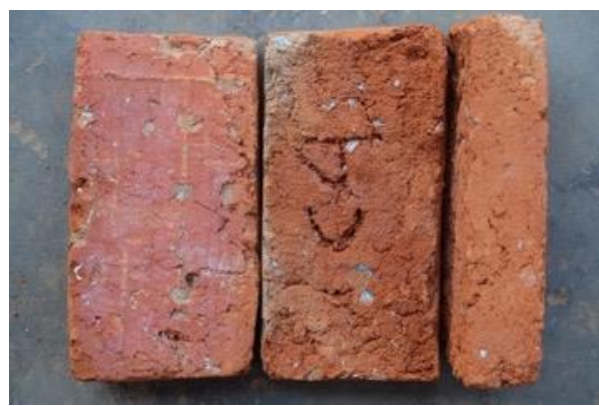

Figure 7. C4: Vinyl $440 \mathrm{gr} / \mathrm{m}^{2}$ pieces.

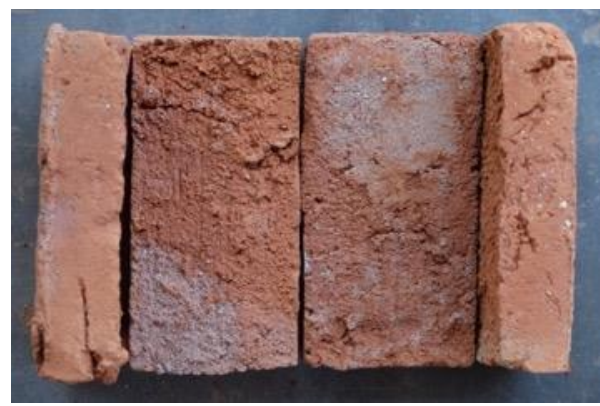

Figure 6. S: RHA.

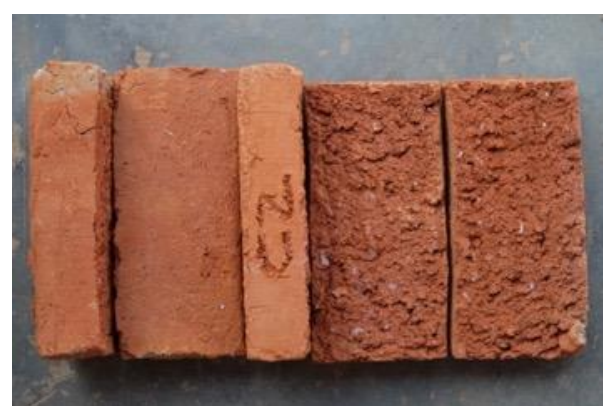

Figure 8. C2: Vinyl 280gr $/ \mathrm{m}^{2}$ pieces. 


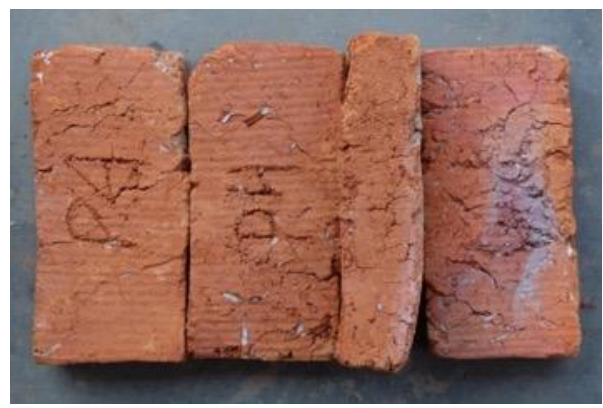

Figure 9. P4: Vinyl $440 \mathrm{gr} / \mathrm{m}^{2}$ threads.

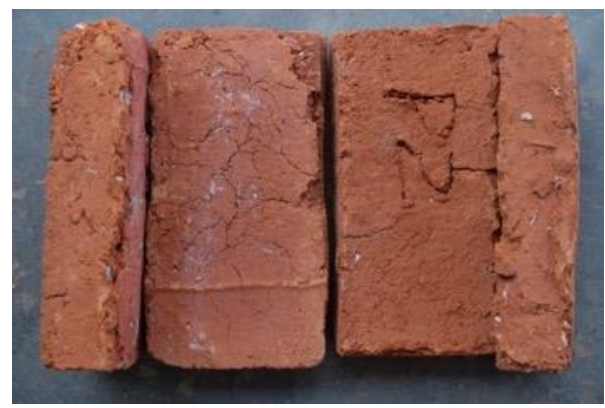

Figure 10. P2: Vinyl 280gr/m² threads.

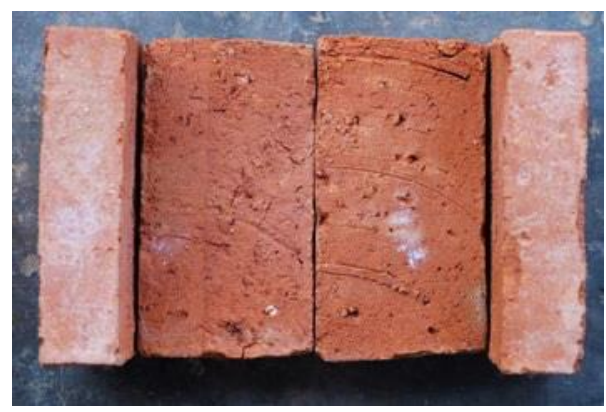

Figure 11. M: Pure fired clay brick.

First suspect which causes bumpy appearance on those bricks above is manual shaping technique. It was using simple wire to cut dough above block of mould. As it can be seen in Figure 8 which $\mathrm{C} 2$ has smooth finish on one side and rough on other side. This can be happened due to wire cutting imperfection on wet dough. Also, it can be seen other images from Figure 12 through Figure 18, waste-added clay bricks are slightly bent and have uneven outer skin. Shortly after each wet clay is shaped manually, its form remains intact as a nearly perfect block. However, during sun-dried process the moisture content start to evaporate irregularly due to vinyl pieces and threads unevenly distributed within the bricks blocking the moisture. Since production cannot control amount and position of waste within bricks, the only approach that possibly can be done is applying certain ratio as can be seen in Table 3. However pure fired-clay bricks achieve good shape since its wet content material evaporates equally through all sides and edges. Hence, its final form remains solid, dense, and heavy. From this result it can be easily predicted that market tend to buy fired-clay brick which has good appearance and consistency in terms of shape.

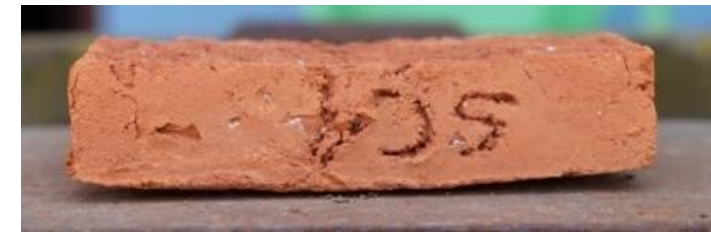

Figure 12. SC4: RHA + Vinyl 440gr/m² .

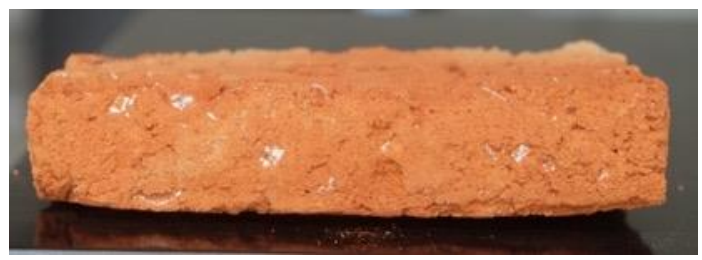

Figure 14. C4: Vinyl 440gr/ $/ \mathrm{m}^{2}$.

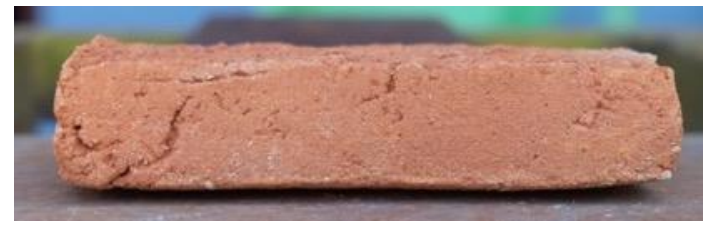

Figure 13. S: RHA.

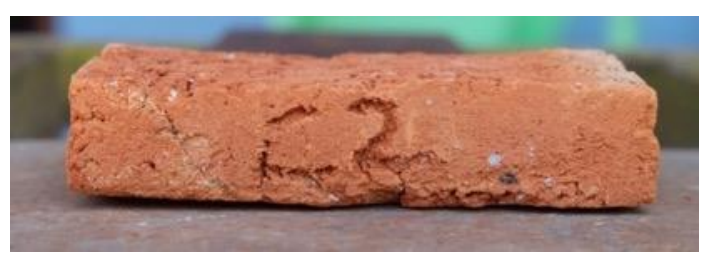

Figure 15. C2: Vinyl 280gr/ $/ \mathrm{m}^{2}$. 


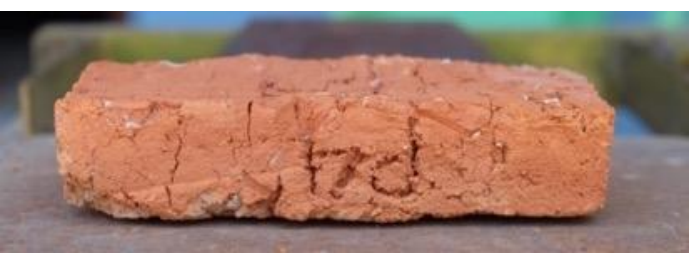

Figure 16. P4: Vinyl $440 \mathrm{gr} / \mathrm{m}^{2}$.

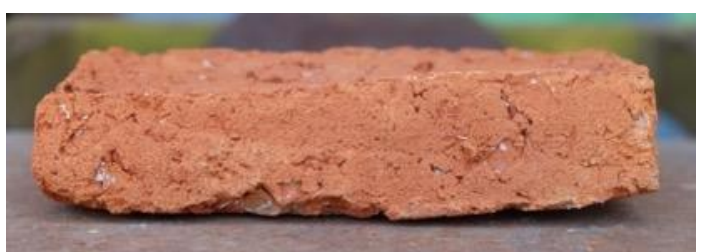

Figure 17. P2: Vinyl 280gr/m².

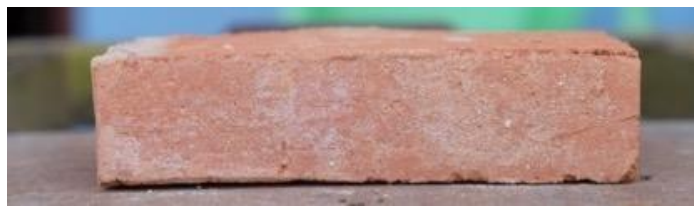

Figure 18. M: Pure fired clay brick.

Water absorption average test result as long as 1 minute, 5 minutes, and 24 hours can be seen in Figure 19 below. Our control test result with $M$ code is defined as averaged water absorption potential for pure fired-clay bricks, while other test results with SC4, RHA, C4, C2, P4, and P2 are showing main interest in this study. The effect of adding vinyl waste differs one of another. Experiment label for C4, C2, P4, and P2 show tiny difference in terms of immersed water over time. Once bricks soak in the water these four samples will instantly absorb water as much as they can do. However, rice husk ash (RHA) waste results in the code of SC4 and RHA show slow water absorption and both of them gradually remain to draw in such amount of water from 1 minute up to 24 hours. Eventually after 24 hours, both RHA-added and vinyl waste-added have higher water absorption performance than the pure one.

Water Absorption Test

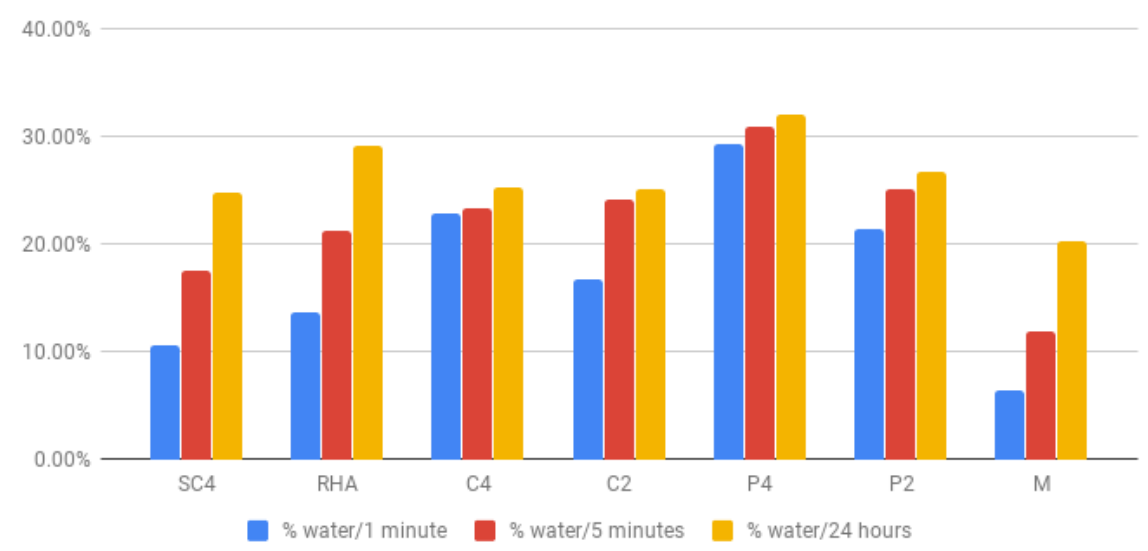

Figure 19. Percentage of water absorption test for all fired-clay bricks experiment.

Bricks masses information are available in Table 4. All forms start with same dimension, but in the process some clay bricks shrink irregularly. Water content in the mix also contributes to its final shape and final mass. Hence, all that reasons make its mass or density different one another.

Table 4. Average fired-clay bricks masses.

\begin{tabular}{cccccccc}
\hline Type & SC4 & RHA & C4 & C2 & P4 & P2 & M \\
Average mass (gram) & 865.1 & 883.5 & 885.7 & 867.3 & 958.1 & 944.5 & 1039 \\
\hline
\end{tabular}


Density results cannot be easily achieved due to bumpy outer skin at most of fired-clay bricks. Dimension size measurement is not valid because of surface unevenness. Furthermore, volume and density are not able to be derived from it. As consequence, further study is needed to provide bricks density calculation. For the present study, Table 4 only shows average masses for seven types of bricks which have experimented. It is evident that pure fired-clay bricks (M) have denser and heavier body than the rest of waste-added products. Even though all bricks begin with same size in molding phase, each experiment model will develop independently although under the same sun-dried condition and even burnt in the same kiln.

Vinyl waste fill the gap in the middle of wet clays, this reduces amount of clays which also lower the final weight measured. This also has taken effect on its porosity, as can be seen in Figure 19 bricks of $\mathrm{C} 4, \mathrm{C} 2, \mathrm{P} 4$, and P2 have connected hole. For those clay bricks, water can easily infuse the whole body as the result there is no much weight different of water between 1 minute, 5 minutes, and surprisingly 24 hours too. The opposite example applies for SC4, RHA, and also M, their porosity might not plainly relate from the surface to the core. As the result, the percentage of water absorption still continue after hours soaking under water.

\section{Conclusion}

It can be concluded that it is possible to incorporate vinyl waste into fired-clay bricks fabrication although temporarily their appearance is not broadly well accepted. By adding vinyl waste into clay dough, at last it helps decrease the weight and or the density. Vinyl-added bricks also effortlessly draw in more water up to $11 \%$ than the pure bricks. Furthermore, all waste-added bricks both incorporating rice husk ash (RHA) and vinyl have higher water absorption capacity than the pure bricks. The lightest brick happens to be SC4 (rice husk ash + vinyl pieces $440 \mathrm{gr} / \mathrm{m}^{2}$ ) at average mass of $865.1 \mathrm{gram}$, whereas the heaviest brick turns out to be M (pure and normal fired-clay bricks) at average mass of 1039 gram.

\section{References}

[1] Kizinievič O, Kizinievič V, Pundiene I, Molotokas D. Eco-friendly fired clay brick manufactured with agricultural solid waste. Archives of Civil and Mechanical Engineering [Internet]. Elsevier $\quad$ BV; $2018 \quad$ Sep;18(4):1156-65. Available from: http://dx.doi.org/10.1016/j.acme.2018.03.003.

[2] Muñoz Velasco P, Morales Ortíz MP, Mendívil Giró MA, Muñoz Velasco L. Fired clay bricks manufactured by adding wastes as sustainable construction material $-A$ review. Construction and Building Materials [Internet]. Elsevier BV; 2014 Jul;63:97-107. Available from: http://dx.doi.org/10.1016/j.conbuildmat.2014.03.045.

[3] De Silva GHMJS, Perera BVA. Effect of waste rice husk ash (RHA) on structural, thermal and acoustic properties of fired clay bricks. Journal of Building Engineering [Internet]. Elsevier BV; 2018 Jul;18:252-9. Available from: http://dx.doi.org/10.1016/j.jobe.2018.03.019.

[4] Munasih M, Priyasmanu T. Batu Bata dengan Campuran Abu Sekam Padi di Desa Saptorenggo, Kecamatan Pakis, Kabupaten Malang. Industri Inovatif Jurnal Teknik. 2016 Dec 7;6(1).

[5] Kizinievič O, Kizinievič V, Pundiene I, Molotokas D. Eco-friendly fired clay brick manufactured with agricultural solid waste. Archives of Civil and Mechanical Engineering [Internet]. Elsevier BV; 2018 Sep;18(4):1156-65. Available from: http://dx.doi.org/10.1016/j.acme.2018.03.003.

[6] What is clay? - Science Learning Hub [Internet]. [cited 2018 Sep 17]. Available from: https://www.sciencelearn.org.nz/resources/1771-what-is-clay

[7] Ward-Perkins JB. Roman imperial architecture. Yale University Press; 1994.

[8] Fernandes FM, Lourenço PB, Castro F. Ancient Clay Bricks: Manufacture and Properties. Materials, Technologies and Practice in Historic Heritage Structures [Internet]. Springer Netherlands; 2010;29-48. Available from: http://dx.doi.org/10.1007/978-90-481-2684-2_3. 
ICOSITER 2018 Proceeding

Journal of Science and Applicative Technology

[9] Ren KB, Kagi DA. Upgrading the durability of mud bricks by impregnation. Building and Environment [Internet]. Elsevier BV; 1995 Jul;30(3):433-40. Available from: http://dx.doi.org/10.1016/0360-1323(94)00056-x.

[10] Rochadi MT, Irianta FG. Kualitas Bata Merah dari Pemanfaatan Tanah Bantaran Sungai Banjir Kanal Timur. Wahana Teknik Sipil. 2009 Dec 9;12(1):42-50.

[11] Test Methods for Sampling and Testing Brick and Structural Clay Tile. ASTM International; Available from: http://dx.doi.org/10.1520/c0067-07.

\section{Acknowledgments}

This research is part of the project funded by Institut Teknologi Sumatera Research Grant 2018 (Grant No. 205/IT9.C1/PP/2018). 